\title{
Fostering Innovation, Integration and Inclusion Through Interdisciplinary Practices in Management
}

\section{An Overview on Personality Development}

\author{
Dr. Sudhakar D. Bhoite1, Lalita S. Shinde ${ }^{2}$ \\ ${ }^{1}$ Associate Professor, ${ }^{2}$ M.phill Research Scholar \\ ${ }_{1,2}$ Chhatrapati Shahu Institute of Business Education and Research, Kolhapur, Maharashtra, India
}

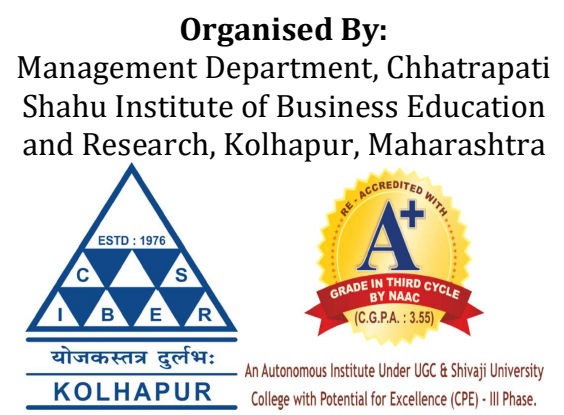

How to cite this paper: Dr. Sudhakar D. Bhoite | Lalita S. Shinde "An Overview on Personality Development" Published in International Journal of Trend in Scientific Research and Development (ijtsrd), ISSN: 2456-6470, Special Issue | Fostering Innovation, Integration and Inclusion Through Interdisciplinary Practices in Management, March 2019, pp.138-141, URL: https://www.ijtsrd .com/papers/ijtsrd 23085.pdf

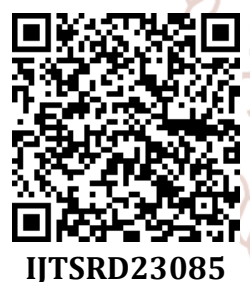

Research methodology

In present study the research used the secondary data which is collected through review of literatures books and internet

\section{Objectives}

1. To understand the concept of personality development

2. To review past study related to personality development

\section{Concept of personality}

Personality means deferent thing of different people. Personality is based or the characteristic set of behavior cognition and emotional pattern that evolve from biological and environmental factors personality is so widely studied concept by the psychologists that personality psychology is taken as a separate discipline of psychology personality psychology is concerned with the analysis of human nature and throes surrounded by the personality. Suppose there are two persons of the same age but have different interests, activities feelings and thinking it mens there is something different inside them, inside is said to be personality all port presented the same concept of personality in his definitions the dynamic organizations with in the individual of those psychophysical system that determines his unique adjustments to his environment.

\section{Determinents of personality}

Different thinkers have listened different determinants of personality this various determinents of personality are brodly classified into three groups

1. Heredity

2. Environment

3. Situation

\section{Heredity}

Heredity refers to biological factors such as qualities from the prents to the children through a biological mechanism physical stature facial attractiueness temperament sex etc, are the examples of heredity that are generally influenced by who ones parents

Parents $\rightarrow$ children $=$ personality 
International Journal of Trend in Scientific Research and Development (IJTSRD) @ www.ijtsrd.com eISSN: 2456-6470

\section{Environment}

Environment generated to a child also experts important influence in shaping his/her personality research studied have also revealed that parents have more effect on the personality development of their children as cpmpared to other members of the family the socialization process starts with the initial contact between a mother and her new infant. They infact gradually come into contact with the social groups outside home/family such as peer, school friends and the members of the work group. Organization itself also contributes much to socialization.

Parents $\longrightarrow$ children $\longrightarrow$ Social Group Fersonality

\section{Situation}

The heredity and environment are the primary determinants of personality but the situation that influence effect of heredity and environment on personality. And individual personality does change depending on the situation because of the different demands of the different situation from different aspects of ones personality for example

The same person while facing an employee and enjoying family lilfe behave quite differently depending on two different situation. Hence personality needs to be looked at situational content not in isolation.

Parents $\rightarrow$ children $\rightarrow$ society $\rightarrow$ situation $=$ personality

\section{Types of personality}

Following are the main types of personality

1. Introvert and extrovert personalities

2. Type A and type B personalities

3. Judging and perceptive personalities

\section{Introvert personalities}

Introvert persons with introvert orientation are primarily oriented to the subjected world. They look inward expensive process their thoughts and ideas within themselves they also avoid social contacts and initiating interaction with other group mares quite.

\section{Extrovert personalities}

Simply speaking extrovert are just contrary to introverts. They refers to the level of comfort ability with relationship to others it represents active assertive talkative out going social energetic and ambitious these people are good in active energy.

\section{Type $A$ and type $B$ personalities}

Type A- these people are characteristic by hard working highly achievement oriented impatient have sence of time urgency aggresicve with competitive drive etc. such people one to be very productive.

Type B- easy-going sociable free from urgency of time noncomperitive are characteristic of type B personality. Such people do better on tasks involving judgements accuracy rather than speed and team work.

\section{Judging perceptive personalities Judging}

People with judging personalities type like to follow a plan make decisious and need only that what is essential for their work.

\section{Perceptive}

These are the people who well to change, want to know all about job and get overcommitted they tend to be curious and welcome new information on a thing or a situation.

\section{Theories of personality}

Personality theories are different from psychology field as well as from other fields dealing with human behavior the theories of personality have been grouped as

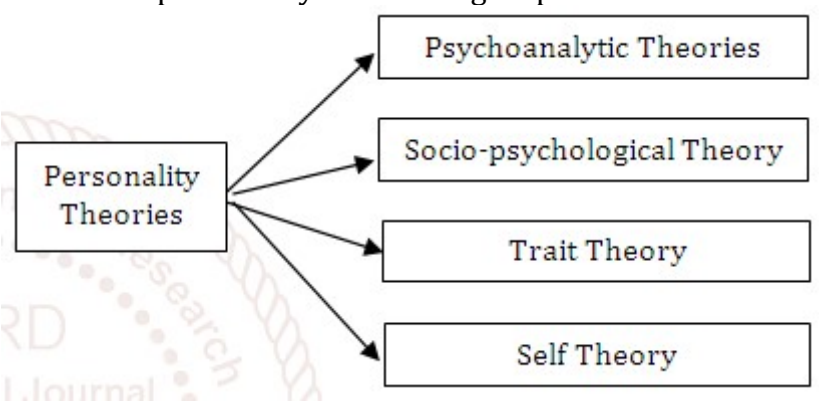

\section{Psychoanalytic theory}

This theory is developed by Sigmund fraud it is based on psychoanalytical theory. Which is based on that human behavior is influced more by unseen forces than conscious and rational though frauds clinical experiments on patiets behavior is mainly influenced by unconscious framework this unconsclous is composed three elements

A. The id - the id is innate and the source of psychic energy. It is immediate gratification for biological needs. The id follows the basic principal of all human life. The id is set of uncoordinated instritucla trends. Different lvels of development and the relations to parental imagos correspond to specific id forms of aggression and affection e.g. to dismember to swallow whole to make disappear etc. the id by immediately reducing tension thus obeys the pleasure principle as id knows and obeys no laws and rules.

B. The ego-the id is unconscious part while the ego is conscious part of human personality the ego is associated with reality is checks the id though ligic and intellect the ego can best be described as controlling id though realities a staruing man can control or satisfy his hunder simply by eating images but reality in satisfying huner or reducing tension. The ego is the organized realistic part that mediated between the desire of the id and the super ego.

C. The super ego- the super ego represents system of values norms and ethic that guide and gouern a person to behave properly in the society. The super ego is conscience it provides norms and values to ego to determine what is wrong or right at a given time in given situation. The super ego judge whether an action behavior is right or wrong as per the set norms and standard of the society. So the id seeks pleasure the ego verifies reality and the super ego strives for perfection. Psychoanalytical theory is an analytic study of the human psyche outliring of the id ego and super ego which is of fundamental importance in the development of psychoanalysis.

\section{Socio-phychological theory}

The socio-psychological theory asserts that individual and society interlinked through this interaction the personality of an individual is determined the socio-psychological is the contribution of Adler Horney forman and Sullivan. 
International Journal of Trend in Scientific Research and Development (IJTSRD) @ www.ijtsrd.com eISSN: 2456-6470

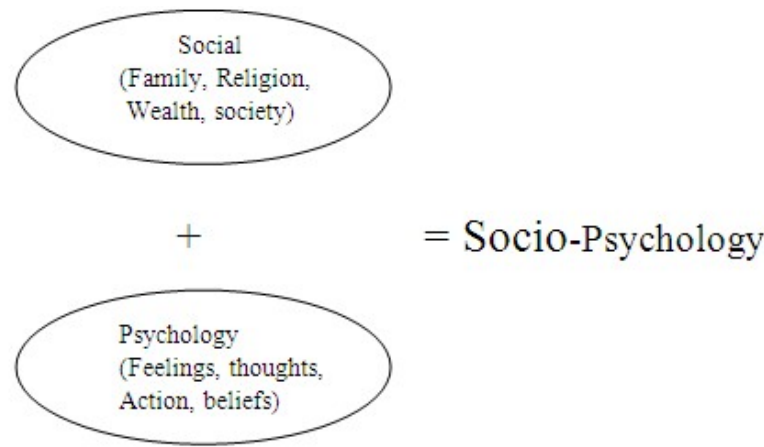

This throry is also called as neo-freudian theory because it differs from the frauds psychoariaytic theory in the following respects.

1. According to this theory the social variables and not the biological iristincts are the important determinants in shaping the individuals personality.

2. Here the motivation is conscious and individual knows what are his needs and wants and what kind of behavior is required to meet these needs.

Thus the theorists belive that socio-psychological factors the combination of noth the social family, society, wealth religion and the psychological factors play an important role in shaping this personality and influences his behaviout according to the external situation.

3. Trait theory

Trait theory is an approach to the study of human personality truit theorists are primarily interested in the measurement of traits which can be defined as habitual patterns of behavior thought and emotions.

$>$ Trait theory of leadership differentiates leaders from non leaders by focusing on personal qualities and characteristic.

$>$ trait theory of leadership sought personality social physical and intellectual traits.

$>$ Trait theory assumes that leaders are born.

\section{Trait theories of leadership}
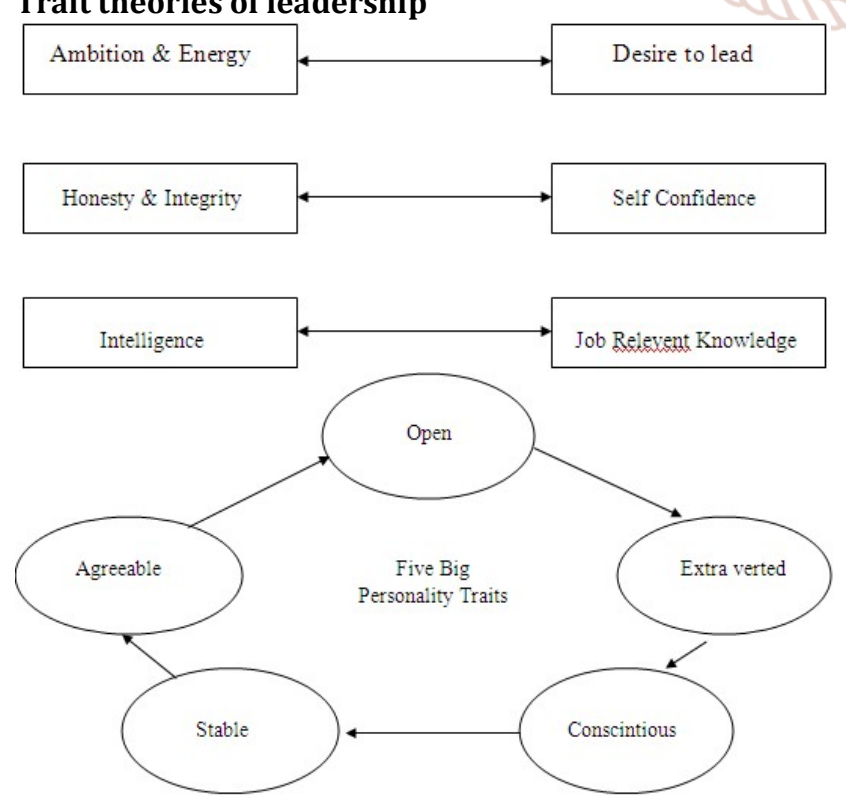

Thus trait theory of personality attempts to understand how a set of personality variables exerts on ones behavior however this theory is very descriptive rather than analytical.

\section{Self theory-}

This theory is introduced by Carl rogers of personality. Carl rogers was a humanistic psychologist who agreed with main assumption of Abraham Maslow but added that for a person to grow they need an environment that provides them with genuineness acceptance (being seen with in conditional positive regard) and empathy (being listended to the understood).

The concept of personality development described by roger is the notion of self or self-concept. This is defined as the organized consistent set of defined about oneself. The self is the humanistic term for who we really are as a person. The self is our inner personality the self is influenced by the experiences a person has in their life and out interpretations of those experiences. Two primary sources that influence our self concept are childhood experience and avalution by others.

The humanistic approach states theat the self is composed of concepts unique to our selves. The self concept includes three components.

1. Self-worth

2. Self-image

3. Ideal-self

1. Self worth-Self worth comparies what we think about ourselves. Rogers belived feeling of self-worth developed in early childhood and were formed form the interaction of the child with the mother and father.

2. Self image-How we see ourselves, which is important to good psychological health self-image includes the influence of our body image on inner personality at a simple level we might perceive ourselves as a good or bad person beautiful or ugly self image affects how a person thinks feels and behavies in the world.

3. Ideal self- This is the person who we would like to be it consists of our goals and ambitions in life and is dynamic forever changing. The ideal self in childhood is not the ideal self in our teens or late twenties etc. this is any attemps of analyzing and understanding organizational behavior the self concept plays a significant role in reacting begaving a particular manner.

How personality develop?

Personality develops with advancement in an individual age passing through certain stages in sequential order. Psychologists and behavior scientists have come out with different stages explain gig how an individual personal develops

\section{A. Sigmand fraud stages of personality}

1. The oral stage (0-1 year)

The oral stage lasts for the first year of ones life is is infancy stage of personality development the stimulation given to the infant both in excessive and inadecuate amounts makes the infant optimistric about the world. 
International Journal of Trend in Scientific Research and Development (IJTSRD) @ www.ijtsrd.com eISSN: 2456-6470

2. The anal stage (2-3 year)

The anal stage extends throughout the second and third year of a child. This stage the anal becomes the gratification. The parents give training to the child gets reflection in adulthood behavior.

3. The phallic stage ( $4-5$ years)

The phallic stage develops at the age of four years. This stage is also characterized as the stage of psychosexual development. The children in this age can be observed examinging and fondling their genitalia and enjoying matters of birth.

4. The latency stage (6-7 years)

The latency stage children's are interested in seeking gratification of the libido from the external sources, knowledge and alike. Hence this period has long lasting effects in ones personality and it shaping in a definite pattern.

5. The genital stage

In this stage adulthood occurs the genital stage the sexual drive in this stage. The genital stage in psychoanalytic is the term used by Freud to described the final stage of human psychosexual development, the individual developers a strong sexual interest in people outside of the family.

\section{B. Eriksons eight life stages -}

Eriksons stages of psychosocial developments as articulated is a comprehensive.

1. Infancy- (0-2)

The first year of life of a person is characterized by trust vs arristrust. The infants raised loving and affection atmosphere learn to trust others this bears long irripact on ones personality

2. Early childhood (2-4)

In early childhood discover our body during this period the child starts to acquired independence when the child is allowed to it hel she feels outonomy. If disallowed a sence of shame and doubt develops in the child.

3. Play age- (4-5)

The child seeks to discover what can be done if the child is allowed and encouraged to do what he /she wants to do the child developers sence of initiative. Alternatively if the child is discouraged to do lack feels lack self confidence.
4. School age- (5-12)

The child joins school from age 5 to 12 years he / she learns knowledge and skills. If the child makes progress with his / her abilities it develops in child a sence of indusing. The opposite results in a sence of inferiority.

5. Adolescence (13-19)

The children during this stage try to gain a sence of identify for them in the society they do not want to become confused about themselves who they are.

6. Young adulthood- (20-40)

The young during their try to develop deep and permanent relationship with others to have a feeling ofintimacy failing in a sence of isolation.

7. Adulthood- (40-65)

The adulthood of their age face the situation the adult generativity adults who are productive in work raise children with series concern and guide next generation.

8. old (65 death).

The adult of integrity gains a sence of wistorn. He appreciates continuinty of past presents and future and becomes fully satisfied.

\section{Conclusion-}

from the in-depth review of past studies on personality development it can be concluded that most of the theories to measure of an individual interaction with its sub-systems like environment and situation.

Reference-

[1] Organization behavior S.S Khanka Chand Repulblication

[2] Personality Gordon w. allport Organization behavior Fred luthans

[3] Principles of management T. Ramasamy Himalaya Republishing House

[4] Internet

Copyright (C) 2019 by author(s) and International Journal of Trend in Scientific Research and Development

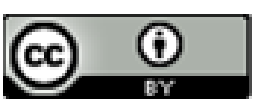
Journal. This is an Open Access article distributed under the terms of the Creative Commons Attribution License (CC BY 4.0) (http://creativecommons.org/licenses/by/4.0) 